\begin{tabular}{|l|l|l|l|l|l|}
\hline J. Tek. Ling & Vol.10 & No.3 & Hal. 249 - 256 & Jakarta, Sept 2009 & ISSN 1441-318X \\
\hline
\end{tabular}

\title{
PEMANFAATAN SALVINIA MOLESTA D.S. MITCHELL, AKUMULATOR MERKURI DI SAWAH TERCEMAR LIMBAH PENAMBANGAN EMAS
}

\author{
Nuril Hidayati, Fauzia Syarif dan Titi Juhaeti \\ Pusat Penelitian Biologi, LIPI \\ Cibinong Science Center JI. Raya Jakarta-Bogor Km 46, Cibinong 16911
}

\begin{abstract}
Mercury is one of important contaminants in mine lands. One approach to remediate risks from this metal pollutant is phytoextraction using hyperaccumulator plants. These remarkable plant species accumulate appreciable high concentrations of metals than do normal plants when the normal plants suffer yield reduction from metal phytotoxicity. Some plant species growing in gold mine contaminated areas indicated high tolerance and potentially effective in accumulating mercury in their roots and above ground portions. Salvinia molesta is one of them. This plant could be utilized as hyperaccumulator for cleaning up mercury contaminated sites. This research aim to study phytoextraction of mercury by Salvinia molesta and the effectiveness of mercury degradator bacteria on plant tolerance and mercury phytoextraction. In this study Salvinia molesta was grown in mercury contaminated liquid gold mine waste, added with Mercury (II) Chloride (HgCl2) 0 ppm Hg, 10 ppm Hg, 30 ppm Hg and 50 ppm Hg. Mercury degradator bacteria was applied in the media. The results showed that Salvinia molesta was able to survive even in media with high level of mercury concentration (50 ppm), although the number of plant survival tend to decrease with the increase of mercury concentration. Variables of surface coverage and live plants decreased with the increase of mercury concentration in the media. There was a close correlation between plant growth variables and mercury concentration in the media. The effects of mercury toxicity on plants seems to decrease in bacteria treated plants. It was indicated by the higher percentage of surface coverage and plant survival in bacteria treated plants than that of untreated plants up to $30 \mathrm{ppm} \mathrm{Hg}$. Recovery from toxicity was shown in bacteria treated plants up to $30 \mathrm{ppm} \mathrm{Hg}$. Mercury accumulation in plants tent to increase with the increase of mercury concentration in media. It can be concluded that plant performance was better and mercury concentration decreased in bacteria treated plants.
\end{abstract}

Key Words: Phytoextraction, accumulator, mercury, bacteria, Salvinia molesta

\section{PENDAHULUAN}

\subsection{Latar Belakang}

Pencemaran merkuri merupakan masalah yang makin meluas akibat dari berbagai penggunaan dalam aktivitas manusia, diantaranya digunakan dalam proses bleaching (produksi klorin, kertas, tekstil), sebagai katalis, pigmen untuk cat, penambangan emas dan bahan agrokimia.

Dalam penambangan emas rakyat merkuri digunakan dalam proses amalgamasi dengan cara tradisional dan limbahnya terbuang begitu saja sehingga menimbulkan pencemaran yang meluas ke lingkungan sekitarnya, termasuk sungai dan lahan pertanian (sawah). 
Merkuri $(\mathrm{Hg})$ mengalami serangkaian reaksi kimia dan transformasi fisik yang komplek dalam siklusnya di atmosfir, tanah dan air. Merkuri mengalami transformasi fisik seperti pencucian, erosi dan penguapan serta mengalami transformasi biokimia seperti metilasi dan reduksi fotokimia. Mobilisasi $\mathrm{Hg}$ dapat terjadi melalui reaksi pertukaran dengan ligan yang mengandung sulfur dan ion klorida, mengakibatkan naiknya kelarutan $\mathrm{Hg}$ di dalam larutan tanah. Di tanah tropis, $\mathrm{Hg}$ berikatan dengan besi dan Al-oksihidroksida dan dapat dimobilisasi dari permukaan tanah melalui aliran air dan erosi. Merkuri menjadi berbahaya karena dapat teroksidasi menjadi $\mathrm{Hg}^{+}$ oleh system biologi dan dapat tercuci ke aliran air sehingga mencemari lingkungan dan terakumulasi pada mahluk hidup dalam bentuk metilmerkuri $\left(\mathrm{CH}_{3}-\mathrm{Hg}^{+}\right)$, dimetilmerkuri $\left(\mathrm{Ch}_{3}\right)^{2}-\mathrm{Hg}^{2+}$ atau garam organomerkuri. Sekali terbentuk metil merkuri ini jumlahnya terus bertambah dan pada top predator seperti ikan, konsentrasinya dapat mencapai jauh diatas batas aman untuk dikonsumsi manusia. ${ }^{1,2)}$

Salah satu cara untuk mengatasi masalah pencemaran oleh merkuri dengan mudah dan murah adalah dengan fitoremediasi, yakni menggunakan tumbuhan hijau yang berfungsi sebagai akumulator merkuri. Fitoremediasi didefinisikan sebagai pencucian polutan yang dimediasi oleh tumbuhan berfotosintesis, termasuk pohon, tumbuhan semak, rumput-rumputan dan tumbuhan air. ${ }^{3)}$

Fitoekstraksi merkuri dapat terjadi karena ion-ion merkuri $(\mathrm{Hg})$ termasuk kelompok ion yang mobile sehingga lebih mudah untuk ditranslokasi ke tajuk tanaman. Merkuri $\left(\mathrm{Hg}^{2+}\right)$ merupakan ion yang mudah untuk disimpan di dalam tempat-tempat penyimpanan seperti vakuola sub seluler, sel epidermal daun dengan kapasitas yang tinggi pada tanaman hiperakumulator. Dalam fitoekstraksi merkuri dideteksi adanya transportertransporter spesifik diantaranya gluthione conjugates sebagai transporter merkuri yang berfungsi memompa ion-ion $\mathrm{Hg}$ ke dalam vakuola. ${ }^{4)}$

Sejumlah tumbuhan terbukti memiliki sifat toleran, yakni dapat mentolelir merkuri dengan konsentrasi tinggi pada akar dan tajuknya serta dapat menyerap dan mengakumulasi merkuri dengan konsentrasi tinggi pada akar dan tajuknya. Hasil penelitian dari Hidayati, Juhaeti \& Syarif menunjukkan bahwa banyak jenis tanaman yang tumbuh di areal Penambangan Emas Tanpa Izin (PETI) yang terkontaminasi merkuri terbukti toleran dan mampu mengakumulasi merkuri dalam jumlah yang tinggi. Jenis-jenis tumbuhan tersebut diantaranya Paspalum conjugatum, Cyperus monocephala, Ipomoea batatas, Zingiber sp, Caladium, Digitaria radicosa (Presl) miq, Commelina nudiflora dan Lindernia crustacea. ${ }^{5}$ Potensi ini dapat dimanfaatkan lebih lanjut untuk membersihkan lingkungan yang tercemar merkuri dengan teknologi fitoremediasi.

Efektivitas fitoekstraksi dapat ditingkatkan dengan memperbaiki faktor internal yakni potensi genetik dan fisiologis tanaman ataupun faktor eksternal seperti aplikasi kelat, manipulasi $\mathrm{pH}$, pemupukan serta aplikasi mikroba seperti bakteri pendegradasi ikatan kimia dari polutan. Diantara perlakuan eksternal yang banyak diterapkan adalah aplikasi mikroba pendegradasi, dalam hal ini adalah mikroba yang berfungsi merombak ikatan merkuri menjadi bentuk yang kurang toksik (aspek mikrobiologi dibahas dalam makalah terpisah).

\subsection{Tujuan}

Tujuan penelitian adalah untuk mengungkap potensi fitoekstraksi Salvinia molesta sebagai tanaman akumulator mekruri untuk fitoremediasi lingkungan (utamanya sawah) tercemar merkuri dari limbah Penambangan Emas Tanpa Izin (PETI). 


\section{METODE PENELITIAN}

Penelitian ini dilaksanakan di rumah kaca, Pusat Penelitian Biologi, LIPI Cibinong. Media tanam berupa limbah cair pengolahan emas dikoleksi dari lokasi Penambangan Emas Tanpa Izin (PETI) di Leuwi Bolang, Desa Bantar Karet, Kecamatan Nanggung, Kabupaten Bogor. Bahan hidup berupa potongan rimpang beserta daun sebanyak $15 \mathrm{gr}$ salvinia ditanam dalam toples kaca berdiameter $+15 \mathrm{~cm}$, tinggi $30 \mathrm{~cm}$, berisikan limbah cair sebanyak $500 \mathrm{ml} /$ toples, yang telah terkontaminasi merkuri $(\mathrm{Hg})$. Perlakuan yang diberikan adalah penambahan merkuri dalam bentuk Mercury (II) Chloride atau $\mathrm{HgCl} 2$ dengan tingkat konsentrasi $0 \mathrm{ppm}$ $\mathrm{Hg}, 10$ ppm Hg, 30 ppm Hg dan 50 ppm Hg. Perlakuan mikroba diberikan pada media dengan pembanding media yang tidak diberi mikroba.

Dalam penelitian ini dilakukan dua perlakuan yakni Perlakuan I: Penambahan $\mathrm{Hg}$ dengan Kosentrasi 0 ppmHg (Kontrol), 10 ppm Hg, 30 ppm Hg dan 50 ppm Hg. Perlakuan II: Pemberian Bakteri perombak $\mathrm{Hg}$ :Salvinia tanpa bakteri (T), Bakteri tanpa tanaman (B), Salvinia + Bakteri (TB), Kontrol atau limbah air PETI tanpa tanaman dan bakteri (K)

Perlakuan dirancang secara acak kelompok dengan tiga ulangan. Parameter yang diukur adalah pertumbuhan tanaman dan kandungan merkuri dalam tanaman yang dianalisis di Laboratorium Balai Besar Pasca Panen dan Badan Litbang Pertanian Cimangu dengan menggunakan metoda AAS.

\section{HASIL DAN PEMBAHASAN}

\subsection{Pertumbuhan Tanaman}

Toleransi tanaman terhadap logam berat ditunjukkan oleh pertumbuhan yang normal tanpa mengalami gejala keracunan hingga tingkat konsentrasi $30 \mathrm{ppm} \mathrm{Hg}$, dan kemampuan akumulasi logam yang tinggi dalam jaringannya pada kondisi lingkungan terkontaminasi. Salvinia termasuk salah satu tanaman yang memiliki toleransi tinggi terhadap logam berat, dalam hal ini merkuri $(\mathrm{Hg})$. Toleransi ini ditunjukkan oleh pertumbuhan dan survivalnya pada media terkontaminasi hingga $50 \mathrm{ppm} \mathrm{Hg}$ (Tabel $1 \& 2)$.

Survival tanaman yang ditunjukkan oleh penambahan biomasa tanaman hidup (berat basah dan berat kering) masih cukup tinggi hingga pada tingkat kontaminasi $30 \mathrm{ppm}$ $\mathrm{Hg}$, walaupun ada kecenderungan menurun dengan meningkatnya konsentrasi $\mathrm{Hg}$. Pada tanaman tanpa diberi perlakuan bakteri, biomasa tanaman menurun proporsional dengan meningkatnya konsentrasi Hg. Pada tanaman tanpa perlakuan bakteri, ada indikasi terjadi pertumbuhan kembali (recovery) setelah mengalami stres toksisitas. Hingga pada konsentrasi $50 \mathrm{ppm} \mathrm{Hg}$, biomasa tanaman yang diberi perlakuan bakteri terbukti masih tinggi, bahkan lebih tinggi dibandingkan pada perlakuan $30 \mathrm{ppm} \mathrm{Hg}$ tanpa bakteri (Tabel $1 \& 2$ ).

Penutupan permukaan oleh tanaman menurun secara signifikan dengan meningkatnya konsentrasi $\mathrm{Hg}$. Pada tanaman yang diberi perlakuan mikroba terjadi pertumbuhan daun baru setelah tanaman mengalami stress toksisitas sehingga penutupan permukaan lebih luas dibandingkan tanaman yang tidak diberi perlakuan mikroba (Tabel 1 \& 2; Gambar 5).

Tingkat kematian tanaman meningkat secara proporsional dengan meningkatnya konsentrasi $\mathrm{Hg}$ baik pada perlakuan mikroba maupun tanpa mikroba. Akan tetapi pada perlakuan mikroba tanaman menunjukkan pertumbuhan kembali setelah mengalami stress keracunan $\mathrm{Hg}$ (Tabel 1 \& 2).

Secara keseluruhan tingkat konsentrasi $\mathrm{Hg}$ dalam media memberikan pengaruh yang signifikan terhadap semua variabel pertumbuhan tanaman yang diamati (pertambahan biomasa tanaman hidup, penutupan permukaan dan tanaman mati). Semakin tinggi konsentrasi $\mathrm{Hg}$ dalam media semakin rendah survival tanaman. 
Performan tanaman tidak berbeda nyata pada perlakuan $\mathrm{Hg}$ konsentrasi $30 \mathrm{ppm}$ dan $50 \mathrm{ppm} \mathrm{Hg}$. Pemberian bakteri perombak $\mathrm{Hg}$ memberikan pengaruh yang signifikan terhadap semua variable yang diamati. Secara keseluruhan performan tanaman lebih baik pada perlakuan pemberian mikroba (Tabel 2).

Pada perlakuan media diberi mikroba terdeteksi adanya pertumbuhan kembali atau revcovery setelah tanaman mengalami stress tolsisitas. Hal ini jelas terlihat pada perlakuan $\mathrm{Hg} 50$ ppm dan $\mathrm{Hg} 30$ ppm dengan mikroba. Tanaman pada kedua perlakuan ini menunjukkan penutupan permukaan lebih tinggi yakni $38.33 \%$ pada $\mathrm{Hg} 30 \mathrm{ppm}$ dan $35 \%$ pada $\mathrm{Hg} 50$ ppm, dibandingkan tanpa perlakuan mikroba masing-masing $25 \%$ dan 15\% (Tabel 1).

Tabel 1. Perbandingan Survival Salvinia molesta pada Berbagai Tingkat Konsentrasi Merkuri dengan Mikroba Perombak Hg (TB) dan Tanpa Mikroba Perombak Hg (T)

\begin{tabular}{|c|c|c|c|c|c|c|}
\hline Perlakuan & \multicolumn{2}{|c|}{$\begin{array}{c}\text { Berat BasahTanaman Hidup } \\
(\mathrm{g})\end{array}$} & \multicolumn{2}{c|}{$\begin{array}{c}\text { Berat Basah Tanaman Mati } \\
(\mathrm{g})\end{array}$} & \multicolumn{2}{c|}{ Penutupan Permukaan (\%) } \\
\hline $\mathrm{Hg}(\mathrm{ppm})$ & $\begin{array}{c}\text { Tanpa } \\
\text { Mikroba }\end{array}$ & $\begin{array}{c}\text { Dengan } \\
\text { Mikroba }\end{array}$ & $\begin{array}{c}\text { Tanpa } \\
\text { Mikroba }\end{array}$ & $\begin{array}{c}\text { Dengan } \\
\text { Mikroba }\end{array}$ & $\begin{array}{c}\text { Tanpa } \\
\text { Mikroba }\end{array}$ & $\begin{array}{c}\text { Dengan } \\
\text { Mikroba }\end{array}$ \\
\hline 0.00 & 36.37 & 27.89 & 1.70 & 1.40 & 93.33 & 100.00 \\
\hline 10.00 & 9.07 & 28.80 & 2.37 & 0.93 & 26.67 & 100.00 \\
\hline 30.00 & 7.60 & 9.60 & 2.67 & 1.80 & 21.67 & 38.33 \\
\hline 50.00 & 4.43 & 8.83 & 3.27 & 4.10 & 15.00 & 35.00 \\
\hline
\end{tabular}

Tabel 2. Hasil Analisa Statistik Tanaman Hidup, Tanaman Mati dan Penutupan Permukaan

\begin{tabular}{|c|c|c|c|c|}
\hline Perlakuan & $\begin{array}{c}\text { Tanaman Hidup (g } \\
\text { BB) }\end{array}$ & $\begin{array}{c}\text { Tanaman Mati }(\mathrm{g} \\
\text { BK) }\end{array}$ & $\begin{array}{c}\text { Tanaman Hidup (g } \\
\text { BB) }\end{array}$ & $\begin{array}{c}\text { Penutupan } \\
\text { Permukaan (\%) }\end{array}$ \\
\hline $\begin{array}{c}\text { Konsentrasi Hg } \\
(\mathrm{ppm}) \mathrm{F}\end{array}$ & & & \\
0.00 & $54.767 \mathrm{a}$ & $1.0793 \mathrm{a}$ & $0.517 \mathrm{~b}$ & $96.667 \mathrm{a}$ \\
10.00 & $37.533 \mathrm{ab}$ & $0.7498 \mathrm{ab}$ & $1.6501 \mathrm{~b}$ & $63.333 \mathrm{~b}$ \\
30.00 & $24.100 \mathrm{bc}$ & $0.4747 \mathrm{~b}$ & $2.233 \mathrm{a}$ & $30.000 \mathrm{c}$ \\
50.00 & $13.000 \mathrm{c}$ & $0.3718 \mathrm{~b}$ & $2.780 \mathrm{a}$ & $27.000 \mathrm{c}$ \\
\hline Mikroba : & & & \\
Tanpa & $24.658 \mathrm{~b}$ & $0.5238 \mathrm{~b}$ & $2.217 \mathrm{a}$ & $39.167 \mathrm{~b}$ \\
Dengan & $42.500 \mathrm{a}$ & $0.853 \mathrm{a}$ & $1.246 \mathrm{a}$ & $73.182 \mathrm{a}$ \\
\hline
\end{tabular}

Ada korelasi yang cukup tinggi antara tingkat konsentrasi $\mathrm{Hg}$ media dengan variabel-variabel pertumbuhan (tanaman hidup, tingkat kematian dan penutupan permukaan). Akan tetapi dengan adanya gejala recovery pada tanaman pada perlakuan mikroba maka korelasi antara tingkat konsentrasi $\mathrm{Hg}$ dan peubahpeubah pertumbuhan menjadi lebih rendah pada perlakuan mikroba dibandingkan perlakuan tanpa mikroba. Pada perlakuan tanpa mikroba korelasi antara konsentrasi $\mathrm{Hg}$ dengan tanaman hidup, penutupan permukaan dan tanaman mati masingmasing $R=0.978, R=0.990$ dan $R=$ 0.982 . Sementara pada perlakuan mikroba korelasi antara konsentrasi $\mathrm{Hg}$ dengan tanaman hidup, penutupan permukaan dan tanaman mati masing-masing adalah $\mathrm{R}=$ 0.883, $R=0.880$ dan $R=0.968$. Hal ini dan iduga disebabkan oleh adanya penurunan toksisitas $\mathrm{Hg}$ dengan adanya mikroba. 


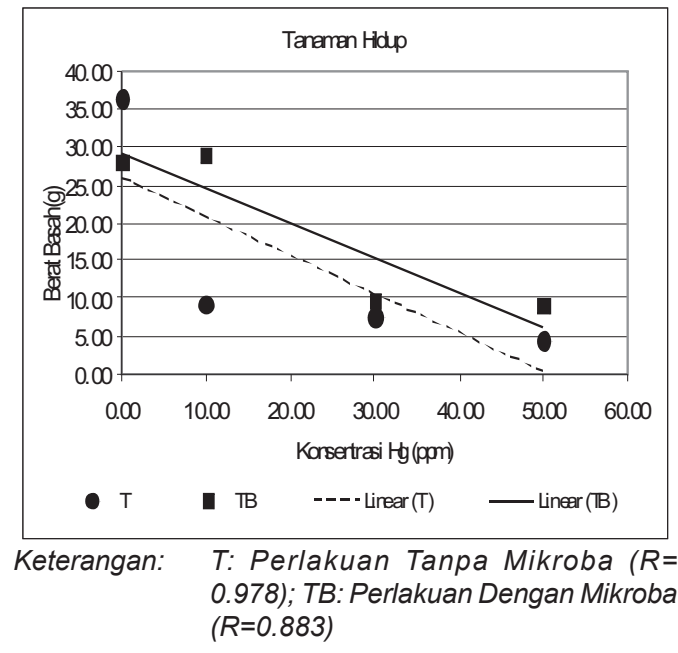

Gambar 1. Korelasi Antara Tanaman Hidup (Survival) dan Konsentrasi $\mathrm{Hg}$ dalam Media

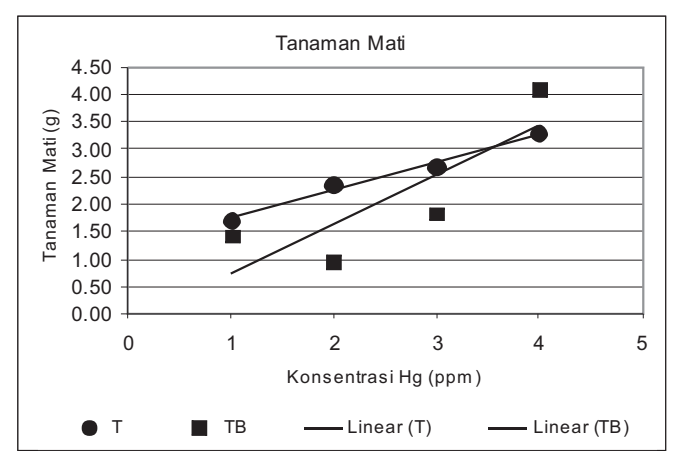

Keterangan: $\quad$ T: Perlakuan Tanpa Mikroba $(R=0.982)$; TB: Perlakuan Dengan Mikroba $(R=0.968)$

Gambar 2. Korelasi Antara Tanaman Mati dan Konsentrasi $\mathrm{Hg}$ dalam Media

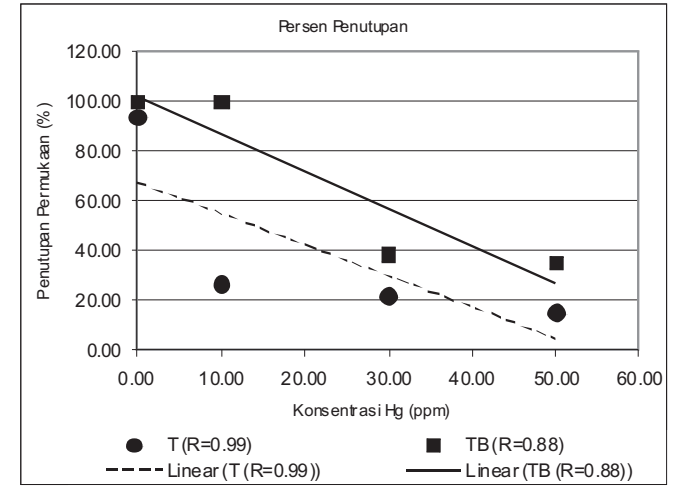

Keterangan: T: Perlakuan Tanpa Mikroba $(R=0.990)$; TB: Perlakuan Dengan Mikroba $(R=0.880)$

Gambar 3. Korelasi Antara Penutupan Permukaan oleh Tanaman dan Konsentrasi $\mathrm{Hg}$ dalam Media

\subsection{Serapan Merkuri pada Tanaman}

Analisis serapan $\mathrm{Hg}$ untuk beberapa sampel masih sedang dalam pengerjaan dan pengulangan untuk mendapatkan hasil yang lebih akurat. Hasil sementara yang dapat dilaporkan adalah sebagaimana yang tertera pada Gambar 4. Akumulasi Hg dalam tanaman cukup tinggi pada perlakuan $\mathrm{Hg}$ $10 \mathrm{ppm}$ dan $30 \mathrm{ppm}$ pada perlakuan tanpa mikroba dan $\mathrm{Hg} 30 \mathrm{ppm}$ pada perlakuan mikroba (Gambar 4).

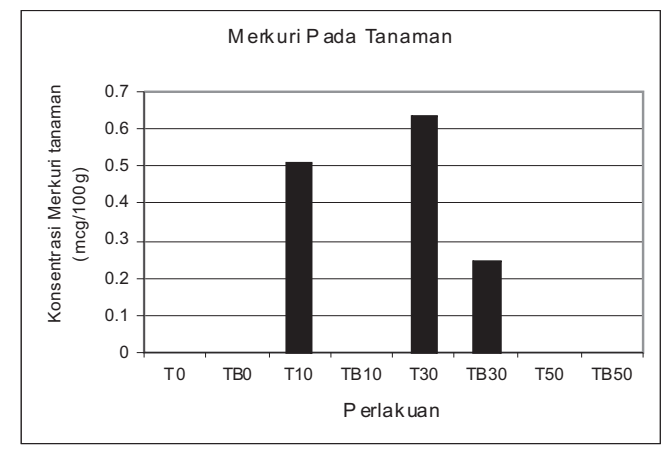

Keterangan: T: Perlakuan Tanpa Mikroba; TB: Perlakuan Dengan Mikroba

Gambar 4. Konsentrasi Hg pada Tanaman pada Berbagai Perlakuan $\mathrm{Hg}$ dan Mikroba. 
Sesuai dengan hasil-hasil penelitian sebelumnya yang melaporkan bahwa kandungan $\mathrm{Hg}$ pada berbagai jenis tanaman akumulator $\mathrm{Hg}$ meningkat dengan meningkatnya tingkat kontaminasi $\mathrm{Hg}$ media. Beberapa penelitian ${ }^{6}$ melaporkan bahwa kandungan $\mathrm{Hg}$ pada beberapa jenis tanaman yang tumbuh pada media yang tidak terkontaminasi $\mathrm{Hg}$ tidak lebih dari $0.1 \mathrm{microg} / \mathrm{g}$, tetapi konsentrasi $\mathrm{Hg}$ dalam tanaman yang tumbuh di tempat yang terkontaminasi $\mathrm{Hg}$ biasanya lebih tinggi. Kandungan $\mathrm{Hg}$ pada kisaran nilai 0.37-3.10 microg/g terdapat pada 5 jenis tumbuhan liar yang dikoleksi dari tanah penambangan Almaden yang terkontaminasi merkuri. Tingkat merkuri sebesar 0.16-1.40 microg/g terdeteksi pada 5 jenis herba yang ditanam di larutan hara yang mengandung $200 \mathrm{microg} / \mathrm{g}$. Kandungan merkuri pada Cyperus monocephala dan Digitaria radicosa meningkat dengan menindkatnya kandungan mekuri pada media. ${ }^{7)}$

Dengan berbagai perlakuan tingkat toksisitas merkuri dapat dikurangi, diantaranya dengan perlakuan kelat dan mikroba. Pada perlakuan kelat kecenderungan bahwa tanaman lebih baik pertumbuhannya. Hasil penelitian sebelumnya melaporkan bahwa aplikasi kelat cenderung memberikan pengaruh pada pertumbuhan dan produksi biomasa tanaman yang lebih baik dibandingkan tanpa kelat, yang terdeteksi pada Cyperus monocephala dan Digitaria radicosa ${ }^{3)}$, Salvinia molesta ${ }^{8)}$, Centrocema pubescens dan Enterolobium cyclocarpum. ${ }^{9)}$ Pada beberapa penelitian disimpulkan bahwa perlakuan kelat terbukti dapat memperbaiki pertumbuhan tanaman walaupun belum dapat meningkatkan fitoekstraksi. Hal ini terjadi karena kelat membentuk ikatan kompleks dengan merkuri sehingga menjadi bentuk yang kurang toksik dan lebih mudah diserap oleh tanaman.

Demikian pula halnya dengan pengaruh mikroba perombak merkuri terhadap pertumbuhan tanaman akumulator.
Pada tanaman yang diberi perlakuan bakteri perombak $\mathrm{Hg}$ terjadi recovery yang ditunjukkan oleh adanya pertumbuhan daun baru. Pertumbuhan daun baru ini terdeteksi setelah tanaman stress dan mati. Recovery pada tanaman yang diberi perlakuan bakteri terlihat pada $\mathrm{Hg} \mathrm{10,30}$ dan 50 ppm. Akan tetapi pada $\mathrm{Hg} 50$ ppm recovery tidak terjadi secepat pada $\mathrm{Hg} 30$ ppm. Diperkirakan Hg $50 \mathrm{ppm}$ merupakan tingkat dimana terjadi hambatan bagi tanaman untuk tumbuh dan recovery. Hal ini diduga karena bakteri yang diberikan dalam media berfungsi dalam merubah $\mathrm{Hg}$ dari bentuk yang toksik menjadi bentuk yang kurang toksik bagi tanaman atau berfungsi dalam menyerap dan mengakumulasi $\mathrm{Hg}$ dalam selnya.

Sesuai dengan temuan Prasat $\mathrm{dkk}^{10}$ bahwa bakteri tertentu mampu memompa logam dari selnya dan mengoksidasireduksi atau memodifikasi ion-ion logam ke bentuk yang kurang toksik. Salah satunya adalah Operon yang mengandung gen yang dapat mendeteksi $\mathrm{Hg}$ (merB), mentransport $\mathrm{Hg}$ (merT), dan penyimpan $\mathrm{Hg}$ dalam periplasmik (merP). MerB mampu mengkatalis pemecahan berbagai bentuk

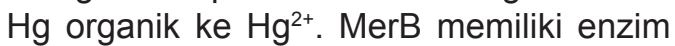
organomercurial lyase yang mengkatalisasi perombakan ikatan karbon menjadi ion $\mathrm{Hg}$.

Pada penelitian ini Salvinia molesta menunjukkan toleransi dan akumulasi $\mathrm{Hg}$ yang tinggi. Berdasarkan kriteria tersebut maka Salvinia molesta dapat dikategorikan sebagai tanaman berpotensi sebagai akumulator merkuri. Untuk mencapai potensi yang lebih optimal masih diperlukan serangkaian penelitian lebih lanjut, termasuk perbaikan potensi genetik dan potensi fisiologis tanaman. ${ }^{10)}$

Perbaikan potensi fisiologis dan genetik ini sudah mulai banyak dilakukan. Beberapa informasi sudah mulai terungkap. Tanaman yang mengalami stres logam berat memproduksi radikal bebas dan oksigen reaktif untuk dapat bertahan terhadap stres sebelum mencapai tahap toleran 
terhadap logam beracun. Glutathione digunakan untuk mensintesis PCs dan dithiol (GSSG). Siklus ascorbate-glutathione terlibat untuk bertahan terhadap stres. Asam organik berperan penting dalam toleransi logam dengan membentuk ikatan kompleks dengan logam untuk mendetoksifikasi logam Metabolisme glutathion dan asam organik sebagai kunci dari sifat hipertoleran logam. Sintesis dari substansi ini dimediasi oleh enzim glutamytcycteine synthase dan glutathionesynthase yang terkait dengan metabolisme sistein dan sulfur. Tanaman transgenik yang dimodifikasi gen PCS dan glutathionesynthase GCS dan GS dan enzim yang terkait dengan metabolisme sulfur i.e serine acethyl transferase mulai banyak diteliti. ${ }^{9)}$

\section{KESIMPULAN DAN SARAN}

Dari hasil penelitian ini dapat disimpulkan:

1. Pertumbuhan salvinia paling baik ditunjukkan oleh kontrol dan perlakuan $\mathrm{Hg} 10$ ppm.

2. Pertumbuhan salvinia secara umum lebih baik pada perlakuan mikroba dibandingkan perlakuan tanpa mikroba.

3. Pertumbuhan salvinia terhambat dengan meningkatnya konsentrasi merkuri $(\mathrm{Hg})$.

4. Penutupan permukaan oleh tanaman menurun dengan meningkatnya $\mathrm{Hg}$

5. Kematian salvinia meningkat dengan meningkatnya konsentrasi $\mathrm{Hg}$

6. Ada indikasi pertumbuhan kembali setelah keracunan (recovery), terutama pada perlakuan mikroba

7. Pemberian mikroba memberikan pengaruh pada pertumbuhan tanaman yang lebih baik pada tingkat konsentrasi $\mathrm{Hg}$ hingga 30 ppm. Pada konsentrasi 50 ppm (TB50) tidak ada indikasi (recovery)

\section{DAFTAR PUSTAKA}

1. Moreno, F.N., CWN Anderson and Stewart, R.B., 2005a. Effect of thioligands on plant-Hg accumulation and volatilisation from mercurycontaminated mine tailings. Plant and Soil 275: 233-246.

2. Moreno, F.N., Anderson, C.W.N., Stewart, R.B., \& Robinson, B.H., 2005b. Mercury volatilisation and phytoextraction from base-metal mine tailings. Environmental pollution vol. 136: 341-352).

3. Chaney, RL., Brown, SL., YM Li, Angle, JS., Homer, F., Green, C., 1995. Potential use of metal hyperaccumulators. Mining Environ Management 3(3):9-11.

4. Meagher, RB., \& Heaton, AC., 2005. Strstegies for the engineered phytoremediation of toxic element poluution : Mercury and arsenic. J. Ind. Microbiol.Biotechnol 32 (1112):502-513.

5. Pusat Penelitian Biologi-LIPI. 2007. Laporan Teknik .1127 hal.

6. Rodriguez, L,, Rincon, J., Asencio, I., \& Rodriguez, CL. 2007., Capability of selected crop plants for shoot mercury accumulation from polluted soils: Phytoreemdiation perspectives. Int. J. Phytoremediation 9(1): 1-13

7. Hidayati, N., Syarif, F., \& Juhaeti, T., 2009. Fitoekstraksi Merkuri pada Cyperus monocephala Endl. dan Digitaria radicosa Presl. Miq yang Ditanam pada Media Terkontaminasi Merkuri dengan Perlakuan Kelat dan $\mathrm{pH}$. (Dalam proses publikasi di Jurnal Biologi Indonesia). 
8. Juhaeti, T., Syarif, F., dan Hidayati, N., 2008. Potensi Salvinia molesta D.S. Mitchell, Limnocharis flava (L.) Buchenau dan Monochoria vaginalis (Burm.f.) Presl Untuk Fitoekstraksi Merkuri di Sawah yang Tercemar Merkuri Akibat Kegiatan Penambang Emas Tanpa Izin (PETI). (Dalam proses publikasi di Jurnal Bidiversitas).

9. Suhertina, T., 2009. Pengaruh Merkuri dan Aplikasi Kelat Terhadap Morfologi Tanaman Enterolobium cyclocarpum
(Willd.) Griseb dan Centrosema pubescens Benth. Sebagai Alternatif Fito-Akumulator Merkuri. Laporan Kerja Praktek Program Studi Biologi FMIPA Institut Teknologi Sepuluh Nopember Surabaya.

10. Prasat, MNV., \& Frietas, HMO., 2003. Metal hyperaccumulation in plants-Biodiversity prospecting for phytoremediation technology. Electronic J.of Biotechnol. 6(3):Des. 2003. 